\title{
THE AUTHORITY OF PEOPLE'S CONSULTATIVE ASSEMBLY BY SUBSQUENT OF THE AMENDMENT OF THE 1945 CONSTITUTION OF THE REPUBLIC OF INDONESIA
}

\author{
Sanidjar Pebrihariati.R \\ Faculty of Law, Universitas Bung Hatta, Padang \\ Email: sanidjar72@gmail.com
}

\begin{abstract}
People's Consultative Assemly (hereinafter reffered to $M P R$ ) membership consisting of members of the House of Representative (hereinafter reffered to $D P R$ ) and Regional Representative Council (hereinafter reffered to $D P D$ ) members indicates that the $M P R$ is still viewed as a representative body of the people because of its membership elected in the general election. The change of position of the People's Consultative Assembly $(M P R)$, then the understanding of the form of popular sovereignty is reflected in three branches of power, namely the representative institution, the President, and the holder of the judicial power. Problem formulation discussed are: 1) How is the position of the People's Consultative Assembly as the implementer of people's sovereignty in Indonesia before the amendment of the 1945 Constitution? 2) How the position of MPR members coming from the DPD after the Amendment of the 1945 Constitution of the Republic of Indonesia. The research method used in this research is Normative Law research method, which uses secondary data. The discussion in this research: 1) the MPR as the executor of the sovereignty of the People in Indonesia, prior to the 1945 amendment, we see in the provisions On Article 1 paragraph (2) of the 1945 Constitution stipulates that: "Sovereignty is in the hands of the people, and carried out according to the law basic". In the above article it contains three meanings, namely: a). The sovereignty of the people is implemented by all state institutions established in the Constitution, b). The sovereignty of the people must be subject to the constitution, c) constitutional supremacy. People's sovereignty is limited by the rules of the Constitution and constitutional democracy. 2) Position of MPR members originating from DPD after the Amendment of the 1945 Constitution of the Republic of Indonesia. After the fourth amendment of the 1945 Constitution, (hereinafter referred to as the 1945 Constitution of the Republic of Indonesia), there is a fairly fundamental change in both the state administration system and the state institutions in Indonesia .
\end{abstract}

Keywords: MPR, Position, Sovereignty

\section{A. INTRODUCTION}

The presence of MPR in the representation system is seen as a distinctive feature of the democratic system in Indonesia. MPR membership consisting of members of the $D P R$ and $D P D$ members indicates that the MPR is still viewed as a representative body of the people because of its membership elected in the general election. Elements of $D P R$ members to reflect the principles of political 
democracy while the elements of $D P D$ members to reflect the principle of regional representation so that regional interests are not neglected. With the change of the position of the $M P R$, the understanding of the sovereignty of the people is reflected in the three branches of power namely the representative institutions, the President, and the holder of judicial power.As an institution, the MPR has the authority to amend and enact the Constitution, elect President and / or Vice President in case of vacancy President and / or Vice President, inaugurating the President and / or Vice President, and the authority to dismiss the President and / or Vice President according to the Constitution. In the context of the exercise of authority, although members of the House of Representatives have a larger number of $D P D$ members, but the role of $D P D$ in the MPR is very large, for example in terms of changing the Constitution which must be attended by $2 / 3$ MPR members and dismiss the President which must be attended by 3/4 MPR The role of the DPD in that authority is a necessity. In conjunction with the People's Legislative Assembly, specifically regarding the holding of MPR sessions relating to the authority to dismiss the President and / or Vice President, the process can only be done if it is preceded by the opinion of the DPR submitted to the MPR. 24C Paragraph (1) of the 1945 Constitution states that one of the authority of the Constitutional Court is to decide upon the dispute over the authority of state institutions whose authority is granted by the Constitution. Because of the position of the $M P R$ as a state institution, if the $M P R$ disputes with other state institutions which have the same authority determined by the Constitution, then the conflict must be resolved by the Constitutional Court.

\section{B. PROBLEMS}

Based on the introduction, the author aims to find out two problems as follow:

1. How is the position of MPR as the executant of people's sovereignty in Indonesia prior to the amendment of the 1945 Constitution?

2. How is the position of MPR members coming from the DPD after the Amendment of the

1945 Constitution of the Republic of Indonesia?

\section{RESEARCH METHODS}

This study uses a "normative juridical research 'conducted by examining 
the library materials or secondary data (Soerjono Soekanto dan Sri Mamudji, 2010: 13). Furthermore, secondary data supported by primary data through field research by interviewing relevant resource persons and experts on this issue. The research was supported by the law also by the legal historical method, comparative law and the law that will come (CFG Soenaryati Hartono, 2006: 144146). This normative juridical research using primary, secondary and tertiary legal materials.

\section{RESEARCH RESULT AND DISCUSSION}

I. The Position of the People's Consultantive Assembly as the Executant of the Sovereignty of the People

The position of the People's Consultative Assembly as the executant of the sovereignty of the People in Indonesia, prior to the amendment of the 1945 Constitution, this can be seen in the provisions of Article 1 Number (2) of the 1945 Constitution, stipulated that:

"Sovereignty is in the hands of the people, and carried out according to the constitution".

In the above article it contains three meanings, namely:

a. People's sovereignty is exercised by all state institutions established in the Constitution,

b. People's sovereignty should be subject to the Constitution: the supremacy of the constitution.

c. People's sovereignty is limited by the rule of the Constitution: constitutional democracy

Based on the above article, the State of the Republic of Indonesia based on the 1945 Constitution, embraces the principle of people's sovereignty. The principle of the sovereignty of the people gives connotation which is based on the sense that the highest authority within the State of the Republic of Indonesia based on the 1945 Constitution is in the hands of the Indonesian people. So in the political system of people's sovereignty, it is the people who have the ultimate power to give and or to determine the final political decisions. In this case, if there is a political decision of the people then the consequences of all parties, both the ruler and the people themselves must obey and execute it, without any reason that can be used to conduct irregularities or misappropriation, unless it is allowed (determined so) according to the legislation Apply. That is according to the rules of the game of the democratic system (Zainun Buchari, 2001: 56) 
The Characteristics of a Country that Adheres to the People's Sovereign Principles Characteristics of the State that embraces the principle of People's Sovereignty, this time characteristic.blogspot.com will characterize the characteristics of the State that adheres to the principle of People's Sovereignty as follows:

1. People's representative institutions are elected

2. The composition of membership membership shall be stipulated by the Constitution.

3. Has a representative body of the people;

4. Sovereignty is in the hands of the people and carried out according to the Constitution.

Jean Bodin argues that absolute and supreme authority is essential to a state in order to regulate all citizens and others within the scope of its territory. However, in relation to the power that the ruler possesses, since it is acquired within a certain period of time, the ultimate power can not be called sovereignty. The ruler is merely a means to carry out the will of the party who gives power to him (Jean Bodin, 1995: 70).

At present, after reform, it is no longer possible, to request and or to obtain direct political decisions from all the people for all sorts of problems and on an ongoing basis, so as to reflect that the principle of people's sovereignty in the country is always implemented Directly and purely. The reason why it can not be implemented again, presumably due to several things, namely:

a. The people of the country in general are large,

b. The territory of the country is generally broad, moreover consisting of islands,

c. Political affairs in the field of politics, at the present time is very complex, diverse kinds, not as simple as in ancient times,

d. The state of the people of a country at this time is already heterogeneous, especially the level of education and knowledge.

e. The people of a country at this time have been preoccupied with their own affairs.

Therefore, generally countries that adhere to the principle of people's sovereignty, in the present time, its pure reality is carried out every time steadily and continuously by running the election. In this case, the election intends to 
establish a body or institution that becomes a representative representative of the people (represent the will of the people). The objective of the formation of a body or a representative institution of the people themselves, is to delegate (delegate) the power to exercise the sovereignty of the people, from all the people as the owner, to the representative institution, as the holder of power (mandataris) from the people.

If the system of delegation to exercise supreme state power is not carried out, there will be difficulties, since it is impossible for all the people of a country of millions, to run the power of the highest state at all times, to determine the political decision by all the people of a country regarding Various fields are continuously impossible. For in practice to establish a decision by a large group of people will be more accomplished when compared with decision-making by a group of far less members.

This is even more visible when the smaller group is a member of an institution prepared to know and understand the problem, so it is relatively easy to determine the attitude or action to solve it. In fact, in the practice of state administration, the kinds of political decisions to be settled amount to not a few and diverse fields. If to take or determine a verdict it has taken a long time, then there will be a buildup of problems, so it will result in less smooth implementation of state governance.

The establishment of representative bodies or representative bodies that function as the holder of the power of sovereignty, and to exercise the power of the state, this means that it can be done the formation of a clean state government and in accordance with the will of the people so dignified.

In addition, the election in this case also means the occasion of the transfer of state power from the old holder to the new holder in accordance with the will of the people peacefully without bloodshed, so that there will be no coup'd eta "(power struggle by force).

The principle (principle or basis) of the people's sovereignty is that all the people who hold supreme authority within the Unitary State of the Republic of Indonesia. In practice the implementation of the principle of popular sovereignty in the community, can be seen or proven, such as the people elect the representatives of the people or government officials.

a. Prior to 2002 in Indonesia, the people voted: 
1. Members of the People's Legislative Assembly (in a liberal democracy);

2. Constituent members;

3. Members of the People's Legislative Assembly as part of the MPR (plus regional delegates and Class);

4. Governor, regent, village head, or lurah.

b. According to the 1945 Constitution of Article 6A, the people elect the president directly in the presidential election in 2004.

c. According to Law Number 12 Year 2003, the people also vote (in the election);

1.Members of Parliament, consisting of:

a. Members of political parties participating in the general election

b. There are 550 people

2. Members of DPD, consisting of:

a. Provincial representatives

b. Each province is set by 4 people

c. All DPD members are no more than $1 / 3$ of the total members of the DPR

3. Members of Provincial DPRD, consisting of:

a. Members of political parties participating in the general election

b. At least 35 people and as many as 100 people

4. Members of the Regency or Municipal DPRD, consisting of:

a. Political members of the election participants

b. At least 20 people and up to 45 people

Prior to the Amendment of the 1945 Constitution of the Republic of Indonesia (NRI 1945), a state structure was founded on the highest authority, in the hands of the MPR, which fully exercised the sovereignty of the people. This resulted in the absence of checks and balances in the constitutional institutions, among others:

1. The 1945 Constitution gives a very great power to the executive power (President). The system adopted by the 1945 Constitution is an executive heavy: the dominant power is in the hands of the President supplemented by various constitutional rights commonly called prerogative rights (among others: granting pardons, amnesty, abolition and rehabilitation) and legislative power because they have the power to form laws. 
2. The 1945 Constitution contains articles that are too "flexible" and "flexible" so that it can lead to more than one interpretation (multiple interpretations), such as Article 7 of the 1945 Constitution (before the amendment).

3. In the 1945 Constitution too much authorizes the power of the President to regulate the important matters with the Law. The President also holds the legislative powers so that the President can formulate important matters according to his will in the Act.

4. The formulation of the 1945 Constitution of 1945 on the spirit of state administration has not been sufficiently supported by constitutional provisions containing basic rules of democratic life, the rule of law, the empowerment of the people, respect for human rights and regional autonomy. This opens up opportunities for the development of state management practices that are inconsistent with the Preamble of the 1945 Constitution, among others as follows:

a. The absence of checks and balances between state institutions and power centered on the president.

b. Infra structure established, among others political parties and community organizations.

c. General Election (election) is held to meet the requirements of formal democracy because the whole process of implementation is controlled by the government.

d. Social welfare based on Article 33 of the 1945 Constitution is not achieved, it is evolved is a system of monopoly and oligopoly.

A state institution is a central government institution whose functions, duties and authorities are strictly regulated in the Constitution. Overall, the 1945 Constitution of the State of the Republic of Indonesia (UUD 1945) before the change recognizes the six highest / highest state institutions, namely the People's Consultative Assembly as the highest state institution; DPR, President, MA, BPK, and DPA as state high institutions. However, after the amendment, the 1945 Constitution states that the state institutions are MPR, DPR, DPD, President, BPK, MA, MK, and KY without knowing the term of high or highest state institution. The 1945 Constitution embodies the principle of sovereignty which is reflected in the governance arrangements of the state. 
The 1945 Constitution contains the regulation of the rule of law, the people, and the state because in it regulates the law-based power sharing, the process of organizing the sovereignty of the people, and the relationship between the Republic of Indonesia and the foreign countries in the context of international relations. Besides regulating the process of power sharing, On the relationship of authority and working mechanism among state institutions in the administration of the state (Miftah Thoha, 2008: 45) To be able to examine the relationship between state institutions, we need to look at the key concepts used in the system of Indonesian state thinking.

The principle of popular sovereignty embodied in legislation is reflected in the institutional structures and mechanisms of state and government to ensure the establishment of the legal system and the functioning of the democratic system.

From an institutional standpoint, the principle of popular sovereignty is usually organized through a system of separation of power or distribution of power. Separation of powers tends to be horizontal in the sense that power is separated into functions reflected in the equal and checks and balances of state institutions, whereas the distribution of power is vertical in the sense that the manifestation of power is shared vertically down to the institutions High state under the institution of people's sovereignty (H.R. Ridwan, 2006: 78)

During this time, the 1945 Constitution adheres to the idea of dividing power that is vertical. People's sovereignty is regarded as a full manifestation of the MPR which is the highest state institution [Article 1 paragraph (2), before the amendment]. From these functions certain functions are shared as duties and powers of the state institutions under it, namely the President, DPA, DPR, BPK, and MA.

In the 1945 Constitution (before the change) there is no known strict separation, but based on the outcome of the change, the principle of horizontal separation of powers is clearly embraced, for example the separation between the executive power holders in the hands of the President [Article 5 paragraph (1)] and the holder of power Legislative council which is in the hands of Parliament [Article 20 paragraph (1)]. To know how the process of organizing the state according to the Constitution, the Principle of separation and distribution of power should be observed because it greatly affects the relationship and institutional 
mechanisms between state institutions. With the affirmation of these principles, as well as to show the characteristic of constitutionalism in force in order to avoid any arbitrariness of power.

II. Position of MPR Members from DPD after the Amendment of the 1945 Constitution of the Republic of Indonesia.

After the fourth amendment of the 1945 Constitution, (hereinafter referred to as the 1945 Constitution of the Republic of Indonesia), there is a fairly fundamental change in both state administration and state institutions in Indonesia. This can be seen from the abolition of the position of the MPR as the highest state institution as well as the existence of several new state institutions established, namely the Regional Representative Council and the Constitutional Court. In addition, the position of all state institutions is equal as a state high institution. The institutions listed as state institutions according to the 1945 Constitution of the Republic of Indonesia are:

1. Majelis Permusyawaratan Rakyat (MPR);

2. House of Representatives (DPR);

3. Regional Representatives Council (DPD)

4. President;

5. Supreme Court (MA)

6. The Constitutional Court (MK)

7. Supreme Audit Agency (BPK)

The amendment to the 1945 Constitution has created a constitutional system based on the balance of power (checks and balances), ie each power is limited by law based on their respective functions. In addition, the improvement on the position and authority of each state institution is adapted to the development of modern democracy (Wasistiono Sadu, 2009: 101), one of which affirms the presidential government system while still taking the elements of parliamentary government as an effort to cover up the shortage of presidential government system. Members of the People's Consultative Assembly (MPR) consisting of members of DPR and DPR have experienced changes in authority.

\section{House of Representatives (DPR)}

The existence of amendments to the 1945 Constitution, greatly affect the position and authority of the House of Representatives as a legislative 689 |Yustisia Vol. 6 No. 3 (September-December 2017) The Authority Of People's .. 
body. One of them is the granting of power to the House to form a law, which previously held by the president and the House of Representatives is only entitled to give approval only. This change also affects the relationship between the House of Representatives as the legislative body and the president as the executive body, namely in the process and the mechanism of the formation of the Act. In addition, the amendment of the 1945 Constitution also reinforces the functions of the DPR, namely: the function of legislation, budget function, and supervisory functions as a control mechanism between state institutions. (Article 20 A Paragraph (1) of the 1945 Constitution of the Republic of Indonesia)

\section{Regional Representatives Council (DPD)}

As a new state institution established after the amendment to the Constitution, the DPD was formed with the aim of accommodating regional interests as a form of regional representation at the national level. This is also a follow-up to the elimination of regional delegates and group representatives as members of the MPR. Similarly, like members of DPR, DPD members are also elected directly by the people through the election. (Article 22 C Paragraph (1) of the 1945 Constitution of the Republic of Indonesia). DPD has the authority to propose and participate in discussing RUU related to regional autonomy, central and regional relations, other draft related to regional interest. (Article 22 D Paragraph (1) and (2) of the 1945 Constitution of the Republic of Indonesia).

Based on the 1945 Constitution, the House of Representatives now consists of DPR and DPD. The difference between the two lies in the nature of the interests it represents, the DPR to represent the people while the DPD to represent the regions (Sunarno Siswanto, 2009: 80) In Article 20 paragraph (1) states that the House holds the power to form laws. Furthermore, in order to strengthen the position of DPR as a legislative power holder, Article 20 Paragraph (5) stipulates that in the case of a jointly approved bill not authorized by the President within 30 days of the approval of the bill it shall become law and shall be enacted.In connection with DPD, There is a working relationship in terms of participating in discussing the Bill related to a particular field, the DPD gives consideration to 
certain Bill, and conveys the results of supervision on the implementation of certain laws in the DPR. In relation to the Constitutional Court, there is a working relationship in the case of the DPR's request to the Constitutional Court to examine in relation to the opinion of the People's Legislative Assembly regarding the allegations that the President and / or Vice President have been guilty of allegation.

In addition, there are other working relationships such as in case of any dispute with other state institutions, the process of nominating candidates for constitutional justices, and the process of submitting the opinion of the People's Legislative Assembly which states that the President is guilty of being questioned by the Constitutional Court.

In conjunction with BPK, the DPD under the provisions of the Constitution receives the results of the BPK audit and gives consideration to the election of members of BPK. This provision gives the DPD the right to make the results of BPK's financial statements as material in the context of carrying out its duties and authorities, and to participate in determining the membership of BPK in the process of selecting members of BPK. In addition, BPK's report will be used as a material to propose and considerations regarding the Bill on State Budget. In relation to the Constitutional Court, there is a working relationship relating to the authority of the Constitutional Court in case of any dispute with other state institutions.

\section{E. CLOSSING}

\section{Conclusion}

1. The position of the People's Consultative Assembly as the implementer of the People's sovereignty in Indonesia before Amendments to the 1945 Constitution, are: "Sovereignty is in the hands of the people, and carried out according to the constitution". In the above article it contains three meanings, namely:

a. People's sovereignty is exercised by all state institutions established in the Constitution;

b. People's sovereignty shall be subject to the Constitution: the supremacy of the constitution. 
c. People's sovereignty is limited by the rules of the Constitution: constitutional democracy

2. The position of MPR members originating from the DPD after the 1945 Amendment of the 1945 Constitution of the Republic of Indonesia is: Based on the 1945 Constitution, now the People's Consultative Assembly consisting of DPR and DPD. The difference between the two lies in the nature of the interests it represents, the DPR to represent the people while the DPD to represent the regions. In the provision of Article 20 Paragraph (1) states that; The House holds the power to form laws. Furthermore, in order to strengthen the position of the People's Legislative Assembly as a holder of legislative power, in the provision of Article 20 Paragraph (5) it is stipulated that in the case of a jointly approved bill not approved by the President within 30 days of the approval of the bill, DPD gives consideration to certain bill, and convey the result of supervision of certain law implementation in Parliament. In relation to the Constitutional Court, there is a working relationship in the matter of the request of the Parliament to the Constitutional Court to examine in relation to the opinion of the People's Legislative Assembly regarding the allegations that the President and / or Vice President have allegedly guilty.

\section{Suggestion}

1. It must be clear, the MPR relationship with the Court of Koonstitusi, especially in the case of a Constitutional Court decision related to the dismissal of President / Vice President;

2. It should be clear the equivalence of the working relationship between the House and the DPD, as a member of the People's Consultative Assembly.

\section{BIBLIOGRAPHY:}

\section{Books:}

Buchari Zainun, 2001, Manajemen Sumber Daya Manusia (Human Resource Management), Jakarta: Radja Grafindo Persada. 
Thoha, Miftah 2008, Birokrasi Pemerintahan Indonesia di Era Reformasi (Indonesian Government Bureaucracy in the Reform Era), Jakarta: Prenada Media.

Ridwan H.R, 2006, Hukum Administrasi Negara (Law of State Administration),. Jakarta: Radja Grafindo Persada.

Siswanto Sunarno, 2009, Hukum Pemerintahan Daerah di Indonesia (Law of Local Government in Indonesia), Jakarta: Sinar Grafika.

Sadu Wasistiono, 2009, Meningkatkan Kinerja DPRD (Improving DPRD Performance), Fokus Media, Jakarta.

Suhartono, Sunaryati, 2006, Bhineka Tunggal Ika Sebagai Asas Hukum Bagi Pembangunan Hukum Nasional (Bhineka Tunggal Ika As Legal Principle for Developing the National Law), Bandung: Alumni

\section{$\underline{\text { Regulations: }}$}

The 1945 Constitution of The Republic of Indonesia;

Law Number 23 of 2014 on Local Government, State Gazette of The Republic of Indonesia Number 244 of 2014);

Law Number 9 of 2015 on the Second Amendment of Law Number 23 of 2014 on Local Government Number 24 of 2015;

Law Number 17 of 2014 on $M P R, D P R, D P D$, and $D P R D$, State Gazette of The Republic of Indonesia Number 182 of 2014 